\title{
Can lecturers reflect on the influence of Moodle curricular on students' success?
}

\section{Cedric Bheki Mpungose}

Discipline of education and Curriculum Studies, School of Education, University of KwaZulu-Natal, Durban, South Africa

How to cite this paper: Mpungose CB. (2019). Can lecturers reflect on the influence of Moodle curricular on students' success? The Educational Review, USA, 3(10), 127-134.

http://dx.doi.org/10.26855/er.2019.10.001

*Corresponding author: Cedric Bheki Mpungose, Discipline of education and Curriculum Studies, School of Education, University of KwaZulu-Natal, Durban, South Africa. Address: Private Bag X03, Ashwood, 3605. Phone: $+27(0) 312603671$; Mobile: $+27(0) 726455606$; Fax: +27(0)864474259

Email: mpungosec@ukzn.ac.za

\begin{abstract}
An important development in higher education is the demand to adopt new educational technology and information to frame student success. In response, Moodle Learning Management Platforms (LMP) provide informal and formal curricula which brings challenges to lecturers and they seem reluctant to embrace it for student success. This article presents a qualitative critical action research of three out of eight lecturers. Purposive with convenience sampling were used to choose the three most accessible lecturers who were teaching science modules. The article aimed to explore lecturers' reflections on the impact of Moodle curricula on student success. The lecturers' reflective activity and one-on-one semi-structured interview were utilized for data generation. This was driven by two research question namely: what are lecturers' reflections on and in the use of Moodle curricula to attain student success? and why do lecturers reflect on and in use of Moodle curricula using particular ways to attain student success? Inductive and deductive processes were used to ensure qualitative guided analysis of the generated data. Triangulation, transferability, dependability, confirmability and credibility was maintained to ensure trustworthiness. The study concluded that lecturers were using formal reflections to be more familiar with formal curriculum than informal curriculum of Moodle, and this impaired student success. Consequently, this article recommends lecturers to use reflective process to align informal with formal Moodle curriculum in order to attain student success.
\end{abstract}

\section{Keywords}

curriculum, Moodle, reflections, science modules, student success

\section{Introduction}

The ever changing conditions on political and socio-economic status reshape higher education institutions (universities) around the world (Africa, Asia, Australia, the United States and Europe), and this pressures higher education management to adopt emerging LMP such as Moodle, Blackboard and others for implementation of curriculum in order to attain student success (university throughput or outcomes) (Waghid- \& Davids, 2016). Note that, "Institutions, educators and students in higher education are increasingly challenged by governments to contribute to national economic achievement. One aspect of this challenge is a drive to improve student success" (Zekpe \& Leach, 2010, p. 166). In response to this, universities in developing countries like South Africa, Ghana, Nigeria, and others have adopted Moodle LMP to manage teaching and learning of modules. Moodle is a free-open-source software LMP which stands for Modular Object-Oriented Dynamic Learning Environment used for teaching and learning of module content (formal curriculum). It is designed for social constructivist learning (Informal curriculum) (Jackson, 2017). In other words, Moodle LMP consists of both informal curriculum (horizontal curriculum) and formal curriculum (Vertical curriculum) which plays a major role to drive teaching and learning in order to attain student success (Anderson, 2016; Khoza \& Mpungose, 2017). Surprisingly, the lecturers' lack of bringing an alignment between these two Moodle curricula has had 
negative impact on students success, and is becoming the world wide challenge that is required to be tackled in order to enhance quality, effective teaching and learning process, especially of science modules (Khoza, 2017). As a result, the next section presents the literature on understanding of student success, Moodle curriculum, and reflections as depicted in figure 1 below

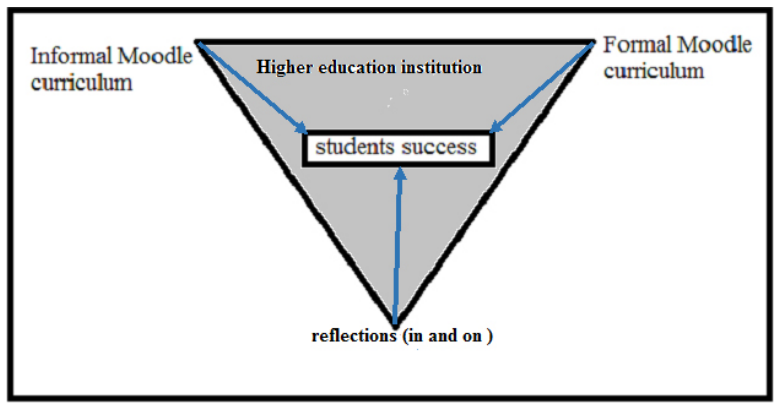

Figure 1. Main pillars framing student success

\subsection{Student success and Moodle}

The literature indicates that in the past few years, student success was not the priority over any other matter in most HEIs but the issues of high figures of enrollment, student grants, infrastructure, and other measurements of success were given the priority (Espinoza-Herold \& Gonzalez-Carriedo, 2017). According to Zekpe and Leach (2010) students success is recently at the centre and becoming the major issue in higher education policies because universities are now funded based on graduation rates, retention, time to degree completion, postgraduates degree completion, job placement and other measures. As a result, student success is referred to as a favorable or desirable student outcome, which may be seen through student retention (re-enrolment of students), educational attainment (degree complete), academic achievements (cum laude and summa cum laude), student advancement (getting jobs you were trained for ) as well as holistic development (intellectual, social, ethical, physical, spiritual development) (Cuseo, 2007; Espinoza-Herold \& Gonzalez-Carriedo, 2017). This suggests that students' success is about embracing the personal development of students in order to address the goals of higher education. Khoza (2017) assert that one of the ways to put the students' best interest first is to create the social platform/programs/practices (informal curriculum) where students can bring in their social experience in order to unpack the module content (formal curriculum) for their own academic excellence. As a result, one way of improving student success in this digital age, is for HEIs to invest in educational technology ( LMPs) like Moodle, and students (digital natives) often do enjoy Moodle LMP more than lecturers (digital immigrants) during teaching and learning (Bates-, 2016). In other words, Moodle LMP consist of informal and formal Moodle curriculum.

\subsection{Informal/horizontal Moodle curriculum}

Informal/horizontal Moodle curriculum places the student at the centre in order to address the student success/needs, teaching and learning is driven by learning outcomes (goals achieved by student at the end of programme) (Bernstein, 1999; Hyland, Kennedy, \& Ryan, 2006). In other words, a student controls teaching and learning by actively engaging in the process through sharing of ideas. According to Govender' and Govender- (2014) facilitation of the content is done on an online Moodle platform where students can use their experiences to unpack the science modules content like acid reaction (Physical Sciences), geometry (Mathematics) and organic molecules (Biology). In other words, software resources like Moodle LMP is actively used to engage students to socially construct their own ideas through social experiences shared during teaching and learning (Khoza \& Mpungose, 2017). Executing of assessment is linked with learning outcomes such that it addresses the module learning outcomes such as allowing the discussion of assessment tasks (discussion forums), and workshops (peer assessments) (Anderson, 2016; Black \& Wiliam, 2009). According to Khoza (2017) lecturers facilitate activities from informal Moodle platform which are student-centred, and they are developed to address student needs in order to attain student success. All the above assertions from the literature (informal Moodle curriculum) seem to make the move to address the current discourse of helping students to succeed, and this suggests that the informal Moodle curriculum (Moodle LMP) is one of the preferred curricula to be used in order to embrace students success. Be that as it may, lecturers are also required to be aware of formal/vertical Moodle curriculum which forms the basis of any other curriculum in HEIs (Schubert, 2009). As a result, the following section will discuss formal/vertical Moodle curriculum. 


\subsection{Formal/vertical Moodle curriculum}

Formal/vertical Moodle curriculum places the module or the subject at the centre during teaching and learning process, and it address the needs of the module offered (Berkvens, van den Akker, \& Brugman, 2014; Bernstein, 1999). These studies further lament that, the teaching and learning process is driven by objectives, defined as goals attained by the lecturers at the end of each programme/lesson. In support of this assertion, the content is prescribed and sequentially followed step by step from the module outline (planned curriculum) based on specific discipline such as Curriculum Studies, Social Science, Engineering, and others (Khoza \& Mpungose, 2017). Moreover, teaching activities are lecturercentred, done on weekly bases, and this allows lecturers to use face-to-face teaching and learning platform such as lecture halls in order to address the module needs (Zekpe \& Leach, 2010). Further to this, Khoza and Mpungose (2017) aver that hardware resources such as data projectors, laptops, desktop computers and others are used to assist lecturer to instruct (lecturers' character) students of what to do following a certain structured patterns. Assessment of learning "tries to summarise the student learning at some point in time and it has been described as end-of course assessment" (Hyland et al., 2006, p. 21). The literature on formal Moodle curriculum indicated above suggests, that this curriculum is only consistent with lecturers needs, the module needs and excludes the needs of student (student success). In other words, it is the basic normativity that lecturers are employed by the university as technicians to deliver the module content (Msibi \& Mchunu, 2013). This suggests that lecturers go to lecture halls to deliver and deposit the content to student without engaging them (student experiences for their success). As a result, this then contradicts with informal Moodle curriculum, and this may hinder student success. In response to this contradiction and confusion between two Moodle curricula (informal and formal), reflection is termed to be the solution (Dewey', 1933).

\subsection{Reflections}

According to numerous studies (Boud, Keogh, \& Walker, 2013; Dewey', 1933; Khoza \& Mpungose, 2017; Pedro, 2005; Schön, 1983; Van Manen, 1991) reflections are regarded as a processes or activities that are central to developing and improving practices in finding the solutions that hinders student success. Further to this, the concept of reflectionon-action and reflection-in-action was introduced in defining reflection phenomenon during teaching and learning of modules in order to attain students success (Schön, 1983). Studies sees reflection-on-action as the process of reflecting effectively on the past experience, and it calls for practitioners (lecturers/teachers) to reflect to see if their practices are aligned to studies/policies of the profession/university in order to support student success. Reflection-on-action is also called formal or vertical (Khoza, 2017). This suggests that this reflection seeks that lecturers reflect on all formal Moodle curriculum signals (objectives, hardware resources, face-to-face platform, assessment of learning, physical permission, character as an instructor, content-centred activities, weekly programmes and science module content) (Berkvens et al., 2014). Furthermore, Reflection-in-action can be defined as the capacity of a practitioner (lecturer) to think and react quickly, within any given present moment, when faced with any perplexing circumstances (Schön, 1983). This reflection is also termed to be informal or horizontal reflections (Khoza, 2017). Moreover, this reflection requires lecturers to reflect in informal Moodle curriculum signals such as learning outcomes, software resources, online platform, assessment as learning, financial permission, character as facilitator, student-centred activities, daily activities and science module content (Berkvens et al., 2014; Bernstein, 1999). Therefore, this discussion on reflection emphasises the use of both reflection in-action and on-action which addresses the module need (formal Moodle curriculum) and student need (informal Moodle curriculum) in order to attain the positive student success as depicted in the figure 2 below. Thus this study seem to be influenced by curriculum spider-web conceptual framework which address the concepts of curriculum.

\subsection{Research purpose/objectives}

Therefore, this article intends to explore lecturers' reflections on and in the use of Moodle curricula to attain student success.

\section{Research questions}

From the lecturers reflections the following two research question were answered:

- What are lecturers' reflections on and in the use of Moodle curricula to attain student success?

- Why do lecturers reflect on and in use of Moodle curricula using particular ways to attain student success? 


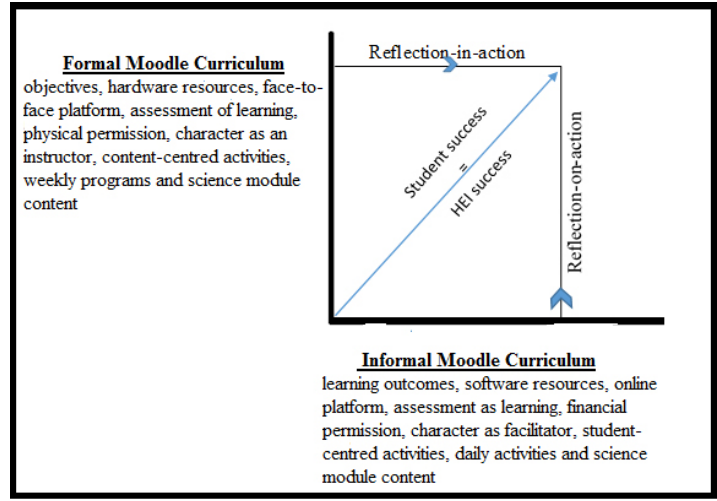

Figure 2. Attainment of student success

\section{Research design and methodology}

\subsection{Paradigm and style}

This is a critical action research study of three lecturers at a South African university. The main purpose of the critical paradigm is to interrogate the phenomenon which in turn may transform the participants (Ramrathan, 2017). Action research deals with a specific context, which may not represent the whole population, with an aim to create a reliable generalisation (McNiff, 2013). However, transferability remains a possibility. Action research is subjective but in-depth, open-ended, exploratory and transformative in nature; it is conducted on entities in their own natural settings where lecturers research their own practices with the aim of improving their teaching situation (McNiff, 2013; Ramrathan, 2017). A combination of the critical paradigm and action research is important for this study because it is transformable, holistic, explorative and contextual in its nature (McNiff, 2013). In other words, lecturers may transform the way they use Moodle LMP in order to attain student success. Moreover, the study used a critical action research process in order to help the participants to learn to plan, implement, observe, and reflect on their behaviour in order to improve their practices (McNiff, 2013). The data were generated from the reflection stage as the final stage of action research.

\subsection{Sampling}

Purposive sampling was used in selecting the only three academics from the population of eight lecturers who used Moodle in teaching science modules at a South African university. Purposive sampling is useful for selecting a specific group with specific unique qualities (Creswell', 2013). The three lecturers were teaching science modules namely Physical Science, Biology and Mathematics. Creswell' (2013) reveals that convenient sampling is referred to as a process of choosing a smaller, more manageable, number of participants who are easily accessible to take part in a study. As a result, I conveniently chose only lecturers who were teaching different science modules using Moodle, who were easily accessible, and who were available to participate in the study.

\subsection{Ethical issues}

The names of lecturers as participants were not revealed because of ethical considerations, as suggested by Cohen, Manion, and Morrison (2013). Informed consent and ethical clearance were acquired and obtained in terms of confidentiality, voluntary participation, and withdrawal whenever they felt the need. Lecturers were made aware of issues of benefit and anonymity in such a way that acronyms (Lecturer 1,2 and 3) were used instead of their real names. The ethical clearance certificate was applied and obtained from the local ethical guidance committee of the university.

\subsection{Data Generation}

Methods used in this study for data generation were reflective journal, and one-on-one semi-structured interviews. The participants kept reflective journals, which they generated and used during their teaching of science modules using Moodle LMP. Thirty minute interviews with each of the participants were conducted twice within which the participants were asked to reflect, through writing, on their use of Moodle LMP. The different questions asked: for example, who advised you to use Moodle LMP? (reflection-in-action); what books/studies/content do you read on the use of Moodle LMP? (Reflection-on-action); and sub-questions for probing were also used (Creswell', 2013; Ramrathan, 2017). The 
interviews were used to add some sub-questions in order to probe for more data and rephrase the questions where necessary in order to accommodate those participants with a tendency to avoid certain questions (Cohen et al., 2013).

\subsection{Trustworthiness}

Multiple sources of data were used for the purpose of enhancing authenticity of data and achieving measures of trustworthiness, and an audio-tape was used to record the interviews for ease of transcription (Ramrathan, 2017). Therefore, the five processes of trustworthiness were involved and observed in this study namely: triangulation (different data sources used), transferability (finding will be beneficial or applicable to others), dependability (direct quotations from participants), confirmability (findings confirmed by participants) and credibility (same sources of data used for similar results) (Cohen et al., 2013).

\subsection{Data analysis}

Moreover, the study utilised qualitative guided analysis, where themes and categories were set while some emerged from the literature and generated data in terms of data analysis, this study used inductive analysis where two themes and categories emerged from the data and literature (Table 1) (Christiansen, Bertram, \& Land, 2010). The codes used for data analysis in theme one were formal Moodle curriculum (driven by reflection-on-action), and informal Moodle curriculum (driven by reflection-in-action) (Khoza \& Mpungose, 2017).

\section{Findings}

Table 1. Themes and categories

\begin{tabular}{|l|l|}
\hline Themes & Categories \\
\hline Formal Moodle Curriculum & $\begin{array}{l}\text { Objectives, hardware resources, face-to-face platform, assessment } \\
\text { of learning, physical permission, character as an assessor, content- } \\
\text { centred activities, weekly programs and science modules }\end{array}$ \\
\hline Informal Moodle Curriculum & $\begin{array}{l}\text { Learning outcomes, software resources, online platform, assessment } \\
\text { as learning, financial permission, character as facilitator, student- } \\
\text { centred activities, daily programs, and science modules }\end{array}$ \\
\hline
\end{tabular}

\subsection{Theme1: Formal Moodle curriculum}

According Jackson (2017) and Bernstein (1999) formal Moodle curriculum is referred to as a curriculum that allows lecturers to use Moodle LMP only for teaching the module content such as science modules; and this curriculum is also called performance, collection, or vertical curriculum. Note the following accounts of lecturers teaching science modules (Physical Sciences, Biology and Mathematics) after they reflected on their action (teaching of modules using Moodle).

Lecturer 1 accounts reflects that, 'Moodle LMP is just been adopted by the university in 2010, it was optional to be used for teaching, and it was made compulsory in 2016 after the university have realized that most lecturers do not use it up to its maximum potential to promote student success. Thus, I started using it in 2016 and my main focus was only to display Biology module content (human anatomy) using my desktop computer having a logon function for password... I found it challenging to engage student on Moodle platform ... I prefer using giving lectures in the lecture hall (face-toface) since I can easily reach my targets (objectives)'. Further to this Lecturer 2 further articulated that, 'I am not use to this Moodle LMP...I always consult Moodle training guide on how to use Moodle activities to teach laws of momentum in Physical Sciences (mechanics)... I was using Moodle quiz and assignment activities driven by the content uploaded on Moodle LMP, and quiz activities was done on weekly basis...'. Whereas, Lecturer 3 stated, 'I only uploaded the content that is going to be assessed during examination including the scope, and also instruct student to download those readings. For instance, I normally upload content on Algebra (various ways of solving for $x$ in a given equation which will be asked during examination)... I accommodate all of kind of student using different transport mode to come early to attend my lecture to avoid disturbance (lecturer controls teaching)' 


\subsection{Theme2: Informal Moodle Curriculum}

Informal Moodle curriculum places the student at the center of teaching and learning process (social constructivism) (Khoza, 2017). Remember that informal Moodle curriculum is also termed as competence (integrated or horizontal) curriculum having its own signals (Learning outcomes, software resources, online platform, assessment as learning, financial permission, character as facilitator, student-centred activities, daily programmes, and science module content) (Bernstein, 1999; Hoadley \& Jansen, 2013). Note that only one lecturer reflected in this theme since all others were not familiar with the use of Moodle LMP.

The all other two lecturers remained silent, but Lecturer 3 reflected that, 'It is interesting to use Moodle platform because my teaching of science content like chemical change in chemistry is made easy, controlled and led by students during discussion in Moodle forum activity...Moodle helps me to track the percentage of each student participation... online platform makes teaching simpler to me since it allows to me upload videos about a certain science content for students to construct their own understanding in order to achieve learning outcomes(social constructivism)....I find it appropriate that only registered student can have access to Moodle LPM and can receive any massages (announcement activity)... the university made it easy to provides each students with Wi-Fi (wireless fidelity) so that it can be easy to access internet for Moodle LMP to download slides....workshop Moodle activity was used to engage student to assess each other before they can sit for any other assessment task...Moodle LMP platform allows me to accommodate all kind of students abilities in learning because I am able to upload science module content using any file format such as PDF, MS word, PowerPoint, Videos and others facilitated on daily basis...I was happy to notice that alignment of learning outcomes with the science content helped my student to pass with flying colours in my module...I allow students actively engage in all module activities on daily basis for holistically development'.

\section{Discussions of findings}

The findings appear to suggest that Moodle LMP provides both informal and formal Moodle curriculum with its signals addressing the module need and student need/success respectively (Hoadley \& Jansen, 2013). However, from the findings the majority of the lectures appear to be well grounded on formal Moodle curriculum (traditional teaching) which is lecturer-centred and driven by the science content during teaching and learning. The teaching of science modules in this curriculum is driven by formal Moodle curriculum signals (Objectives, hardware resources, face-to-face platform, and assessment of learning, physical permission, character as an assessor, content-centred activities, weekly programmes, and science module content) (Berkvens et al., 2014; Bernstein, 1999). This suggests that lecturers are basically focusing on the teaching/delivering of the prescribed science module content from the module outlines, books and other readings. The taught content influences the assessment of learning, and lecturers were employing face-toface platform rather than the online platform so that they can have control of all teaching and learning activities (Khoza, 2017). Moreover, the informal Moodle curriculum seems to drive lecturers to deliver the content using Moodle without engaging students to unpack the content for their success in Higher education.

On the contrary, Moodle LMP is designed for social constructivism where lecturers should provide a platform for students to interact, engage, participate, and share ideas/opinions about the module content being studied (Jackson, 2017). This Moodle LMP provides informal Moodle curriculum with its horizontal signals (Learning outcomes, software resources, online platform, and assessment as learning, financial permission, character as facilitator, studentcentred activities, daily programs, and science module content) (Hoadley \& Jansen, 2013). However, only one lecturer lamented on the proper impact of informal Moodle curriculum by addressing all these signals in order to engage students in unpacking the science module content in order to attain student success. Findings from this curriculum indicates that using Moodle LMP to unpack the content helps students to succeed because their needs are prioritised so that they can excel in their academic progress. Be that as it may, it is still clear from the findings that most lecturers can hardly use emerging LMP which is aimed at addressing student success in HEIs, and one of the reasons is the issue of digital immigrants (lectures) versus digital natives (students). In other words, lecturers needs training before the use of Moodle LMP, whereas student are able to engage with Moodle LMP without any training rendered. Therefore, the literature indicated that any problems faced by lectures in education (reluctance to embrace and balance Moodle curricula), can be solved by the process of reflection (reflection in and on action). This suggests that lecturers can used reflection-on action which address the formal Moodle curriculum and reflection-in-action which address informal Moodle curriculum to balance the two curricula for student success. In other words, the use of Moodle LMP in teaching science seek lecturers to intertwine the use of both Moodle formal and informal curriculum because they seem to unpack the content of modules while addressing the social needs of students. This suggests that lecturers should reflect on their teaching and 
learning practices in order to master and align both formal and informal Moodle curriculum signal in order to attain student success.

\section{Conclusions and educational implications}

This study concludes that lecturers should use reflection-on-action and reflection-in-action to master and align Moodle informal with formal curriculum respectively in order to attain student access in terms of graduation rates, retention, and time to degree completion, postgraduates' degree completion, job placement, and other measures. Alignment of these two Moodle curricula includes lecturers having the best science content knowledge and adequate computer skills to integrate content with Moodle LMP to serve the purpose of social constructivism pedagogy in HEI for student success. Thus, reflection-on-action and reflection-in-action of Moodle is a common intervention in addressing all challenges facing the HEIs with its policies on the use of emerging LMP such as Moodle. The findings further conclude that the lectures' usage of Moodle LMP in teaching science modules was driven by formal Moodle curriculum more than informal Moodle curriculum. This study consequently recommends the use of reflection-on-action and reflection-inaction to align these two Moodle curricula for easy attainment of student success in higher education.

\section{References}

Anderson, T. (2016). Theories for learning with emerging technologies. Emerging technologies in distance education, $7(1), 7-23$.

Bates-, T. (2016). Teaching in a digital age. University of British Columbia.

Berkvens, J., van den Akker, J., \& Brugman, M. (2014). Addressing the quality challenge: Reflection on the post-2015 UNESCO EDUCATION AGENDA. National Commission for UNESCO, 1(2014), 1-30.

Bernstein, B. (1999). Vertical and horizontal discourse: An essay. British Journal of Sociology of Education, 20(2), $157-173$.

Black, P., \& Wiliam, D. (2009). Developing the theory of formative assessment. Educational Assessment, Evaluation and Accountability (formerly: Journal of Personnel Evaluation in Education), 21(1), 5-31.

Boud, D., Keogh, R., \& Walker, D. (2013). Promoting reflection in learning A modeli. Boundaries of adult learning, $1,32-57$.

Christiansen, I., Bertram, C., \& Land, S. (2010). Understanding research. Pietermaritzburg: UKZN Faculty of Education.

Cohen, L., Manion, L., \& Morrison, K. (2013). Research methods in education. England: Routledge.

Creswell', J. (2013). Qualitative inquiry and research design: Choosing among five approaches. Califonia: Sage.

Cuseo, J. (2007). Student success: Definition, outcomes, principles and practices. E-source for College Transitions, 4(5).

Dewey', J. (1933). How we think: A restatement of the reflective thinking to the educative process: Heath.

Espinoza-Herold, M., \& Gonzalez-Carriedo, R. (2017). Issues in Latino education: Race, school culture, and the politics of academic success: Taylor \& Francis.

Govender', N., \& Govender-, D. (2014). Change of Science Teachers' Use of Information and Communication Technology (ICT) Media Resources and its Pedagogical Use in Science Classrooms in a Developing Country.

Hoadley, U., \& Jansen, J. (2013). Curriculum: Organizing knowledge for the classroom: Oxford University Press Southern Africa.

Hyland, A., Kennedy, D., \& Ryan, N. (2006). Writing and Using Learning Outcomes: a Practical Guide. Bologna: European Higher Education Area (EHEA.

Jackson, E. A. (2017). Impact of MOODLE platform on the pedagogy of students and staff: Cross-curricular comparison. Education and Information Technologies, 22(1), 177-193.

Khoza, S. (2017). Is this Moodle for personal, societal and/or professional space/s when students reflect? Paper presented at the Paper presented at the 12th International Conference on E-Learning (ICEL), The Central University of 
Florida, Orlando, USA.

Khoza, S., \& Mpungose, C. (2017). Is the self, them or it come to rescue of turnit in Paper presented at the South Africa International Conference On Educational Technologies (SAICET), Pretoria.

McNiff, J. (2013). Action research: Principles and practices (3rd ed). New York: Routledge.

Msibi, T., \& Mchunu, S. (2013). The knot of curriculum and teacher professionalism in post-apartheid South Africa. Education as Change, 17(1), 19-35.

Pedro, J. (2005). Reflection in teacher education: exploring pre - service teachers' meanings of reflective practice. Reflective Practice, 6(1), 49-66.

Ramrathan, L. (2017). Educational Research: Key concepts. In L. Ramrathan, L. Le Grange, \& P. Higgs (Eds.), Education Studies: for Initial Teacher Development (pp. 403-418). Cape Town: Juta \& Company (Pty) LTD.

Schön, D. (1983). The reflective practitioner: How professionals think in action (Vol. 5126): Basic books.

Schubert, W. H. (2009). Currere and disciplinarity in curriculum studies: Possibilities for education research. Educational researcher, 38(2), 136-140.

Van Manen, M. (1991). Reflectivity and the pedagogical moment: the normativity of pedagogical thinking and acting 1. J. Curriculum Studies, 23(6), 507-536.

Waghid-, Y., \& Davids, N. (2016). Educational Leadership as Action: Towards an Opening of Rhythm. South African Journal of Higher Education, 30(1), 123-137.

Zekpe, N., \& Leach, L. (2010). Improving student engagement: Ten proposal for action. Active Learning in Higher Education, 11(3), 167-177. 